\title{
Przyczynki do działalności wydawniczej Towarzystwa Nauczycieli Szkół Wyższych na przełomie XIX i XX wieku
}

Jedną z organizacji zrzeszających nauczycieli w XIX w. było Towarzystwo Nauczycieli Szkół Wyższych (TNSW) utworzone we Lwowie w 1883 r. ${ }^{1}$

Zajmowało się ono wszechstronnym wspieraniem rozwoju szkół wyższych², rozwiązywaniem spraw związanych z ich działalnością, poprawą sytuacji stanu nauczycielskiego oraz ich rodzin, udzielaniem wzajemnej pomocy, wymianą spostrzeżeń i doświadczeń z zakresu praktyki pedagogicznej, wnoszeniem

* Dr, Państwowa Wyższa Szkoła Zawodowa w Tarnowie, Instytut Administracyjno-Ekonomiczny, Zakład Administracji Publicznej, 33-100 Tarnów, ul. Mickiewicza 8.

1 Kiedy wzrastało zainteresowanie problemami, którymi zajmowało się TNSW, zaczęto tworzyć w miejscowościach, w których mieszkało przynajmniej 10 nauczycieli, koła TNSW. Statut organizacji pozwalał tworzyć w ramach Kół sekcje zajmujące się wybranymi zagadnieniami. Zadaniem Kół było rozwiązywanie wszelkich spraw lokalnych, nie występowały one na zewnątrz jako samodzielne organy TNSW, "Muzeum” 1909, Dodatek 1. A. Karbowiak, Towarzystwo Nauczycieli Szkół Wyższych 1884-1908, s. 10; A. Pachowicz, Instytucje oświatowe w Tarnowie w świetle lokalnej prasy („Unia” 1882-1887), [w:] Czasopiśmiennictwo XIX i początków XX wieku jako źródło do historii edukacji, red. I. Michalska, G. Michalski, Łódź 2010, s. 107; A. Pachowicz, Z działalności Tarnowskiego Koła Towarzystwa Nauczycieli Szkół Wyższych, [w:] Świat słowa. Tom jubileuszowy dla Zofii Cygal-Krupy, red. M. Pachowicz, K. Choińska, Tarnów 2012, s. 688-694. Więcej informacji o funkcjonowaniu całego TNSW w: J. Szafran, Dla dobra polskiej szkoły. Towarzystwo Nauczycieli Szkół Średnich i Wyższych i jego funkcje społeczno-oświatowe w Drugiej Rzeczpospolitej, Poznań 2010, s. 66-69; P. Sosnkowski, 40-lecie Towarzystwa Nauczycieli Szkół Średnich i Wyższych, „Sprawy Towarzystwa Nauczycieli Szkół Średnich i Wyższych" 1924, nr 19, passim; P. Sosnkowski, Dzieje Stowarzyszenia Nauczycielstwa Polskiego 1905-1919, Warszawa 1930, passim; Towarzystwo Nauczycieli Szkół Średnich i Wyższych (przeszłość i teraźniejszość), Warszawa 1938, passim; J. Chodakowska, Towarzystwo Nauczycieli Szkół Średnich i Wyższych i jego udział w reformie szkół średnich w Polsce międzywojennej, „Rozprawy z Dziejów Oświaty” 1986, t. 29, s. 69-106.

2 Kalendarzyk Profesorski Towarzystwa Nauczycieli Szkół Wyższych na rok 1913 ułożony przez M. Janellego i J. Piątka, Lwów 1913, s. 40. 
memoriałów i petycji do władz ustawodawczych, informowaniem społeczeństwa o zagadnieniach związanych z funkcjonowaniem szkół ${ }^{3}$, wydawaniem różnorodnych dzieł o treści naukowej, pedagogicznej, a przede wszystkim własnego czasopisma poświęconego sprawom wychowania i szkolnictwa. Aby w pełni realizować założenia statutowe, TNSW organizowało posiedzenia i zjazdy członków ${ }^{4}$, w trakcie których zapoznawano się ze sprawami edukacji, wygłaszano odczyty, a przede wszystkim dyskutowano nad aktualnym stanem szkolnictwa.

Celem niniejszego opracowania jest próba scharakteryzowania jednego ze statutowych zadań TNSW - działalności wydawniczej w początkowym okresie istnienia Towarzystwa ${ }^{5}$. Stanowiła ona ważny punkt zarówno dla nauczycieli, jak i dla uczniów. Plany władz TNSW w tej kwestii były szerokie. Przewidywały publikowanie własnego pisma oraz innych różnorodnych publikacji, które byłyby przeznaczone z jednej strony dla kadry pedagogicznej (miały przyczynić się do poszerzenia wiedzy i kompetencji, umiejętności nauczycieli), a z drugiej strony dla uczniów (przede wszystkim podręczniki szkolne do poszczególnych przedmiotów).

Realizacja tego zadania początkowo nie była możliwa do wykonania, ponieważ brakowało środków finansowych, „krzyżowały się w tej akcyi i interesy Towarzystwa jako nakładcy i żądania Rady szkolnej krajowej ${ }^{6}$, by ceny książek były jak najniższe, a nareszcie nalegania księgarzy, domagających się wysokiego rabatu. Towarzystwu chodziło o zapewnienie autorom odpowiedniego honorarium bez narażania funduszów wydawniczych na straty a przy tem nie o wygórowany zysk własny, lecz głównie o dobro szkoły, nauki i młodzieży"7.

Pierwszą publikacją TNSW były Wskazówki do nauki języka polskiego. (Na podstawie obrad komisji, wybranej przez Tow. Nauczycieli szkół wyższych) ${ }^{8}$ autorstwa Franciszka Próchnickiego, Lwów 1885 (1000 egzemplarzy) ${ }^{9}$.

W maju 1886 r. Wydział TNSW w trakcie swego posiedzenia podjął decyzję o rozpoczęciu wydawania „Biblioteki Klasyków Łacińskich i Greckich dla Młodzieży Polskiej”. Powołał specjalną Komisję, której zadaniem było przygotowanie planu pracy nad tym wydawnictwem oraz uwzględnianie najnowszych wyników badań naukowych i wskazówek ministerialnych, a ponadto koordynacja wszel-

3 Tamże.

4 „Cenność zaś przynależności do Towarzystwa TNSW tkwi [...] w jego wartościach i możliwościach natury bardziej idealnej. Nie można lekceważyć tej roli, jaką z pracy naukowej, wychowawczej i narodowej w szkole odegrała inicjatywa ze strony nauczycielstwa zgrupowanego w Towarzystwie", „Jednodniówka Towarzystwa Nauczycieli Szkół Wyższych”, Stanisławów 1930, s. 2.

5 Statut Towarzystwa Nauczycieli Szkół Średnich i Wyższych, Warszawa 1920, passim; Statut Towarzystwa Nauczycieli Szkół Średnich i Wyższych, Warszawa 1927, passim; Statut Towarzystwa Nauczycieli Szkół Średnich i Wyższych, Warszawa 1931, passim.

6 Rada Szkolna Krajowa została powołana w 1867 r. na wniosek J. Dietla, istniała do 1921 r., była centralną, autonomiczną instytucją zajmującą się sprawami szkolnictwa, m.in. polonizowaniem szkolnictwa podstawowego i średniego w Galicji, wprowadzaniem podręczników polskich zamiast austriackich. R. Dutkowa, Polityka szkolna w Galicji między autonomią a centralizmem: 1861-1975, Kraków 1995, s. 53.

7 „Muzeum” 1909. Dodatek 1. A. Karbowiak, Towarzystwo Nauczycieli Szkół Wyższych..., s. 62.

8 M. Warmski, Towarzystwo Nauczycieli Szkół Wyższych 1884-1894. Rys historyczny, Lwów 1894, s. 67.

9 „Muzeum” 1909. Dodatek 1. A. Karbowiak, Towarzystwo Nauczycieli Szkół Wyższych..., s. 62. 
kich działań w tej sprawie ${ }^{10}$. Prace edycyjne miały trwać przez kilka najbliższych lat, ponieważ zamierzano „położyć kres importowaniu z zagranicy rzeczy, których produkcya nie przekracza zakresu naszych sił materialnych i moralnych"11.

Wydział TNSW postanowił także wydawać teksty autorów starożytnych. W związku z tym działająca w jego ramach komisja filozoficzna już w 1892 r. przygotowała wstępne propozycje takiego przedsięwzięcia. Planowano również opublikowanie dzieł klasyków specjalnie dla uczniów gimnazjów w języku ruskim. W tej sprawie zwrócono się do Rady Szkolnej Krajowej z prośbą o niezbędną subwencję do realizacji tej koncepcji. Rada aprobowała pomysł, jednak z powodu braku środków finansowych odmówiła wsparcia, dlatego też prac tych nie udało się wydać.

Natomiast spośród dzieł klasyków greckich opublikowano: Chrestomatya z pism Xenofonta opracowane przez Edwarda Fiderera, Lwów 1888, wydanie I (211 stron, 3000 egzemplarzy) ${ }^{12}$, Lwów 1902, wydanie II; lliada Homera w skróceniu, cz. I, wydanie A. Scheindlera do potrzeb gimnazjów polskich zastosował T. Sołtysik, Lwów 1890 (160 stron, 3000 egzemplarzy) ${ }^{13}$; lliada Homera w skróceniu, część II, wydanie A. Scheindlera, do potrzeb gimnazjów polskich zastosował T. Soltysik (259 stron, 2000 egzemplarzy).

TNSW zajęło się także edycją dzieł klasyków łacińskich. Wydano następujące prace: Korneliusza Neposa Żywoty sławnych mężów, w wyborze Wiktora Kłaka, Lwów 1888 (126 stron, 3000 egzemplarzy); M. T. Cycerona: Mowa o naczelnem dowództwie Gn. Pompejusza, wydanie A. Kornitzera, do potrzeb gimnazyów polskich zastosował T. Sołtysik, Lwów 1889 (56 stron, 2000 egzemplarzy) ${ }^{14}$; M. Tul. Cycerona: Kato starszy o starości według wydania A. Kornitzera, a do potrzeb gimnazjów polskich zastosował T. Sołtysik, Lwów 1889 (56 stron, nakład 2000 egzemplarzy) ${ }^{15} ;$ M. Tul. Cycerona: Leliusz o przyjaźni, wydanie A. Kornitzera, do potrzeb gimnazjów polskich zastosował T. Sołtysik, Lwów 1889, wydanie I (55 stron, nakład 2000 egzemplarzy) ${ }^{16}$; M. Tulliusza Cycerona Mowa za Sex. Roscyuszem z Ameryi, wydanie A. Kornitzera, do potrzeb gimnazjów polskich zastosował T. Sołtysik, Lwów 1891 (72 strony, egzemplarzy 2000); M. T. Cycerona Cztery mowy przeciw Katylinie, wydanie A. Kornitzera, do potrzeb gimnazjów polskich zastosował T. Sołtysik, Lwów 1892, wydanie I (78 stron, 2000 egzemplarzy)17; G. Sallustyusza Krispa Wojna z Jugurtą, wydanie G. Linkera i F. Klimschy, do potrzeb gimnazjów polskich zastosował T. Sołtysik, Lwów 1889, wydanie I (129 stron, 2000 egzemplarzy) ${ }^{18}$. G. Sallustyusza Krispa Wojna z Katyliną, wydanie Gustava Linkera, Franza Klimscha, do potrzeb gimnazjów polskich zastosował

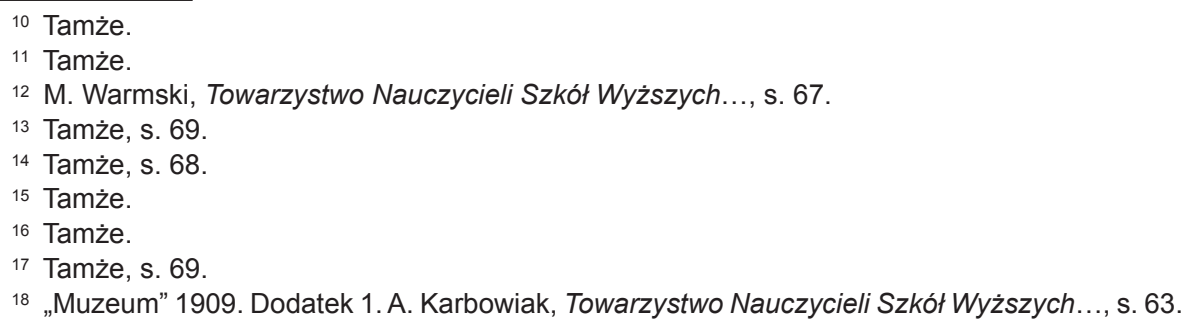


T. Sołtysik, Lwów 1889 (52 strony, nakład 2000 egzemplarzy) ${ }^{19}$; P. Owidyusza Nasona, wydanie K. J. Grysara i K. Ziwsy, do potrzeb gimnazyów polskich zastosował J. Skupniewicz, Lwów 1889 (313 stron, nakład 3000 egzemplarzy); Kw. Horacego Flakkusa wybór pism, wydali J. Dolnicki i S. Librewski, Lwów 1894, wydanie I, Lwów 1909, wydanie II; G. J. Cezara: Wojna gallicka, wydana przez Fr. Terlikowskiego, Lwów 1896, wydanie I, Lwów 1908, wydanie III.

Kolejną sferę działalności wydawniczej TNSW stanowiły podręczniki szkolne. Starano się przygotować nowe edycje dla poszczególnych przedmiotów. Zanim do tego przystąpiono, rozpoczęto szerokie dyskusje m.in. w poszczególnych kołach TNSW, aby uzyskać opinię w tej kwestii jak największej grupy nauczycieli. Sprawę tę uznawano za jedną z ważniejszych i dyskutowano nad nią już w trakcie II Walnego Zgromadzenia w 1885 r.

TNSW zwróciło się do Sejmu Krajowego z prośbą o przywrócenie dotacji krajowej w kwocie 2000 koron i oddanie jej do dyspozycji Rady Szkolnej Krajowej. Zamierzano przeznaczyć ją na nagrody za najlepsze podręczniki dla młodzieży szkół średnich. TNSW zaproponowało także Radzie ustanowienie stałej komisji (pod jej kierownictwem), która miałaby układać plany wydawania podręczników, ogłaszać konkursy, recenzować nadsyłane prace. Starania TNSW przyniosły oczekiwany skutek, Sejm Krajowy przywrócił dotację, określił tryb jej użycia, zgodnie z projektem Towarzystwa, zgodził się także na utworzenie stałej komisji naukowej, jednak nie ustalił zasad, na jakich miałaby działać20.

$\mathrm{Na}$ ten problem zwracał uwagę Bronisław Trzaskowski w trakcie V Walnego Zgromadzenia TNSW. Wówczas rozwiązano go tymczasowo, ustalając, że najpierw zostanie przedyskutowany w poszczególnych kołach TNSW, a później ponownie przed plenum. Wydział TNSW zaprosił wszystkie działające koła do zaopiniowania wniosków B. Trzaskowskiego, rozpatrzenia rozporządzeń ministerialnych, zbadania literatury przedmiotu, natomiast w Wydziale do poszczególnych nauk wybrano osobnych fachowych referentów.

W trakcie VI Walnego Zgromadzenia ustalono więc gotowe postulaty. W 1889 r. Rada Szkolna Krajowa otrzymała od Sejmu Krajowego dotację na wydawanie książek polskich i ruskich, sama ustaliła i opracowała niezbędne zasady. TNSW natomiast domagał się w tym czasie wprowadzenia pewnych zmian w działalności komisji naukowej. Dotyczyły one przede wszystkim jawności recenzji publikacji ${ }^{21}$.

Sprawa rozpisywania konkursów na podręczniki szkolne, o którą starały się najpierw koła, a później dwa kolejne Walne Zgromadzenia (XIV i XV), nie miała powodzenia wobec kategorycznego i uzasadnionego oświadczenia Wydziału, że „konkursy na polu... dydaktyki wtedy są potrzebne, gdy wskutek zaprowadzenia nowego systemu, nowych planów i instrukcyi gwałtowna zachodzi konieczność otrzymania czemprędzej nowych podręczników, lub gdy w zwyczajnych

19 M. Warmski, Towarzystwo Nauczycieli Szkół Wyższych..., s. 68.

20 Utworzenie komisji określanej jako naukowa przyczyniło się do przyspieszenia prac związanych z edycją książek. „Muzeum” 1909. Dodatek 1. A. Karbowiak, Towarzystwo Nauczycieli Szkół Wyższych..., s. 64.

21 Tamże, s. 65. 
warunkach skonstatowano, że jakiś podręcznik jest wprost zły, a konkurencya autorów ma dopomódz do wprowadzenia podręcznika dobrego"22. W obecnej sytuacji nie zachodziła ani jedna, ani druga okoliczność, pozostawało jedynie skierować do Rady Szkolnej Krajowej uzasadnienie, aby rozpisała konkursy, jakie podręczniki trzeba by poprawić. „Do takiego zebrania argumentów potrzeba wiele czasu, wiele trudów i wiele pieniędzy. Temu zadaniu fundusze Towarzystwa nie podołają, a i Rada szkolna nie ma na ten cel dostatecznych funduszów i nie dałaby się do ogłoszenia konkursów skłonić również i z tej przyczyny, że coraz częstsze zmiany instrukcyi, przysyłane z Wiednia, doskonałą książkę dzisiaj, czynią nieodpowiednią, jutro. $Z$ podanych wyżej przyczyn i powodów nie miały powodzenia i późniejsze peryodycznie w Towarzystwie ponawiane wołania o konkursy na podręczniki szkolne"23.

Pierwszy podręcznik wydany nakładem TNSW ukazał się w 1885 r. z dziedziny algebry i arytmetyki: dr Placyd Dziewiński, Zasady algebry dla wyższych klas gimnazyalnych i szkół realnych, Lwów 1891 (384 strony, 3100 egzemplarzy) 24; Lwów 1898, wydanie II oraz kolejne zmienione wydanie tej publikacji Podręcznik arytmetyki i algebry, Lwów 1907. Kolejne podręczniki to: Józef Soleski i Julian Fąfara, Arytmetyka na I. i na II. klasę szkół średnich, Lwów 1894 (100 stron, 2100 egzemplarzy); Antoni Pawłowski, Podręcznik rachunków kupieckich, t. I, Lwów 1902; Tadeusz S. Kistryn, Zarys nauki o handlu, Lwów 1913.

Do nauki chemii opublikowano: Józef Soleski, Zarys chemii dla wyższych klas średnich, Lwów 1892²5; Antoni Sucheni, Zasady chemii z uwzględnieniem mineralogii, Lwów 1904; Arnold Bolland, Bronisław Duchowicz, Chemia organiczna w zastosowaniu do potrzeb klasy VI. szkół realnych, Lwów 190626; Bronisław Duchowicz, Chemia dla liceów, Lwów 1907; Bronisław Duchowicz, Jakościowa analiza chemiczna, Lwów 1905; Bronisław Duchowicz, Chemia zastosowana do potrzeb życia codziennego, Lwów 1907.

Do nauki fizyki nie wydano żadnego podręcznika.

Do nauczania zoologii wydano: Ignacy Petelenz, Zoologia dla klas wyższych szkół średnich, Lwów 1891 (215 stron, 2500 egzemplarzy); do logiki: Władysław Kozłowski, Logika elementarna, Lwów 1891 (104 strony, 2200 egzemplarzy) 27; do nauki religii: ks. Jan Ślósarz: Katechizm religii katolickiej dla młodzieży szkół średnich, Lwów 1897; do nauki kaligrafii: Józef Czernecki, Stanisław Tatauch, Józef Szablowski, Podręczniki do nauki kaligrafii, Lwów 1904 (239 strony); Józef Czernecki, Stanisław Tatuch, Tablice abecadeł normalnych, Lwów 1905.

Do nauki języka łacińskiego TNSW wydało publikacje dr. Zygmunta Samolewicza. Były to: Przykłady do tłumaczenia z języka łacińskiego na polski i z polskiego na łaciński, część I dla I klasy gimnazjum, Lwów 1886 (148 stron, 4000 egzemplarzy); Przykłady do tłumaczenia, część II dla klasy II gimnazyum,

\footnotetext{
22 Tamże.

23 Tamże, s. 65-66.

24 M. Warmski, Towarzystwo Nauczycieli Szkół Wyższych..., s. 69.

25 „Muzeum” 1909. Dodatek 1. A. Karbowiak, Towarzystwo Nauczycieli Szkół Wyższych..., s. 66.

26 Tamże.

${ }_{27}^{27}$ M. Warmski, Towarzystwo Nauczycieli Szkół Wyższych..., s. 70.
} 
Lwów 1887, wydanie III: Zwięzła gramatyka języka łacińskiego dla kl. I i II gimnazyów, Lwów 1889 (84 strony, 3200 egzemplarzy), Lwów 1890, wydanie II (84 strony, egzemplarzy 5000); Lwów 1893 (84 strony, 6300 egzemplarzy); Lwów 1903, wydanie V; Lwów 1907, wydanie VI (226 strony, 6300 egzemplarzy); Gramatyka języka łacińskiego, cz. II: Składnia, opracował T. Sołtysik, Lwów 1891, wydanie V (116 stron, 5500 egzemplarzy); Lwów 1892 (197 stron, 3300 egzemplarzy), Lwów 1906, wydanie VIII'28.

Naukę języka łacińskiego miały ułatwić również Ćwiczenia łacińskie dla klasy I. Według książki Steinera i Scheindlera, Lwów 1893, wydanie I przygotowali A. Frączkiewicz i F. Próchnicki, Lwów 1907, wydanie V²9; Ćwiczenia łacińskie dla klasy II (według książki Józefa Steina i dr Augusta Scheindlera wraz ze spisem wyrazów), Lwów 1894, wydanie I (4300 egzemplarzy); Lwów 1905, wydanie IV przygotowali A. Frączkiewicz i F. Próchnicki; Lwów 1908, wydanie V; F. Próchnicki, Ćwiczenia łacińskie dla IV. klasy, Lwów 1888; Lwów 1905, wydanie III; Korneli Fischer, Henryk Kopia, Preparacya do I. księgi Liwiusza, Lwów 1904, wydanie II30; Jan K. Jędrzejowski, Polsko-łaciński słowniczek frazeologiczny i synonimiczny, Lwów 1906.

Do nauki języka greckiego opublikowano: Edward Fiderer, Gramatyka grecka szkolna, Lwów 1892, wydanie III (232 strony, 4300 egzemplarzy) ${ }^{31}$; Korneli Fischer, Henryk Kopia, Preparacya do Iliady Homera, Lwów 1904, wydanie II23; Korneli Fischer, Preparacya do Platona Apologii, Lwów 1907; Józef Bartunek, Preparacya do Antygony, Lwów 1906.

TNSW wydawało także różnorodne podręczniki do nauki języków nowożytnych. Największą ich część stanowiły te, które dotyczyły języka oraz literatury polskiej. Były to następujące publikacje: Franciszek Próchnicki, Wskazówki do nauki języka polskiego, Lwów 1885; Franciszek Próchnicki, Wypisy polskie dla klasy V szkół gimnazyalnych i realnych, Lwów 1889 (506 stron, 3200 egzemplarzy); Franciszek Próchnicki, Wzory poezyi i prozy dla użytku szkół średnich, Lwów 1893 (504 strony, 5300 egzemplarzy); Lwów 1906, wydanie III.

Stanisław Tarnowski, Franciszek Próchnicki, Wypisy polskie dla klas wyższych szkół gimnazyalnych i realnych, część II, Lwów 1891, Lwów 1892 (792 stron, 3100 egzemplarzy) $)^{33}$; Lwów 1906, wydanie III; Franciszek Próchnicki, Józef Wójcik, Wypisy polskie dla kl. I szkół gimnazyalnych i realnych, Lwów 1908, wydanie V34; Wypisy polskie dla klasy II, Lwów 1907, wydanie III35.

Do nauki języków obcych TNSW także przygotowało odpowiednie publikacje, wydając do języka francuskiego: dr Stanisław Węckowski, Książka do nauki języka francuskiego dla klasy III szkoły realnej, Lwów 1908; do języka niemieckiego:

\footnotetext{
28 Tamże, s. 68.

29 „Muzeum” 1909. Dodatek 1. A. Karbowiak, Towarzystwo Nauczycieli Szkół Wyższych..., s. 67.

30 Tamże, s. 68.

31 M. Warmski, Towarzystwo Nauczycieli Szkół Wyższych..., s. 71.

32 „Muzeum” 1909. Dodatek 1. A. Karbowiak, Towarzystwo Nauczycieli Szkół Wyższych..., s. 68.

33 M. Warmski, Towarzystwo Nauczycieli Szkół Wyższych..., s. 69.

34 „Muzeum” 1909. Dodatek 1. A. Karbowiak, Towarzystwo Nauczycieli Szkół Wyższych..., s. 68.

35 Tamże, s. 69.
} 
ks. Aleksander Pechnik, Synonimika i frazeologia niemiecka dla szkół średnich, Lwów 1891 (87 strony, 2000 egzemplarzy) ${ }^{36}$.

Wraz z powstaniem propozycji dotyczących nauki literatury polskiej z uwzględnieniem jako tła literatury powszechnej, TNSW wydało Przegląd dziejów literatury powszechnej w czterech tomach autorstwa dr Ludomiła Germana (Lwów 1901-1903) oraz do historii powszechnej Aleksandra Semkowicza, Opowiadania z dziejów powszechnych dla niższych klas szkół średnich w trzech częściach, część I: Lwów 1893 (150 stron, 10200 egzemplarzy), 1907, wydanie III; część II, Lwów 1894 (1905, wydanie II)37; część III, Lwów 1895 (1908, wydanie III).

Do historii państwa polskiego ukazały się dzieła: Karol Rawer, Dzieje ojczyste dla młodzieży w czterech wydaniach: wyd. I Lwów 1893; wyd. II Lwów 1895; wyd. III Lwów 1904 oraz wyd. IV Lwów 1908. Natomiast historię Austrii opisali Ludwik Finkiel, Stanisław Głąbiński, Historya i statystyka monarchii austro-węgierskiej, Lwów 1904, wydanie II.

TNSW wydało także do geografii: Eugeniusz Romer, Geografia dla klasy I szkół średnich, Lwów 1904, wydanie II z atlasem; Atlas geograficzny, Lwów 190838; Karol Benoni, Krótki rys geografii, Lwów 1908, wydanie IX39; Julian Mazurka, Krótki rys geografii na I klasę szkół średnich, Lwów 1908.

Od listopada 1890 r. TNSW zaczynało wydawać tzw. „Bibliotekę dla Młodzieży”, czyli nową serię „arcydzieł literatury polskiej i obcej w języku polskim, przystępnych dla młodzieży szkół średnich i stosownych do lektury domowej. W wyborze pragniono uwzględnić nie tylko treść lecz także formę, oraz czystość i poprawność języka i doborowość stylu"40. Wydawnictwo to miało na celu ułatwić młodzieży naukę języka polskiego. W kolejno wydawanych tomikach ujmowano poszczególne zagadnienia.

Tomik I: Karol Szajnocha, Dwie wojny (wyjątek z dzieła Jadwiga i Jagiełło, w opracowaniu Franciszka Próchnickiego), Lwów 1891 (127 strony, 1000 egzemplarzy).

Tomik II: Pedro Calderon de la Barca, Książę niezłomny, Lwów 1891 (123 strony, 1000 egzemplarzy).

Tomik III: Kazimierz Wodzicki, Jaskółka, Lwów 1891 (146 strony, 1000 egzemplarzy).

Tomik IV: William Szekspir, Juliusz Cezar w przekładzie Adama Pajgerta, a w opracowaniu Franciszka Próchnickiego, Lwów 1891 (174 strony, 1000 egzemplarzy).

Tomik V: Kajetan Koźmian, Z pamiętników, z objaśnieniami Piotra Parylaka, Lwów 1891 (175 strony, 1000 egzemplarzy) ${ }^{41}$.

Tomik VI: Józef Szujski, Wallas w opracowaniu Ludomiła Germana, Lwów 1892 (123 strony, 1000 egzemplarzy).

\footnotetext{
${ }^{36}$ M. Warmski, Towarzystwo Nauczycieli Szkół Wyższych..., s. 70.

37 „Muzeum” 1909. Dodatek 1. A. Karbowiak, Towarzystwo Nauczycieli Szkół Wyższych..., s. 69.

38 Tamże.

39 Tamże, s. 70.

40 Tamże.

41 Tamże.
} 
Tomik VII: Karol Szajnocha, Mściciel, wydany przez Franciszka Próchnickiego, Lwów 1892 (172 strony, 1000 egzemplarzy).

Tomik VIII: William Szekspir, Makbet w przekładzie Józefa Paszkowskiego, a w opracowaniu Franciszka Próchnickiego, Lwów 1892 (171 strony, 1000 egzemplarzy).

Tomik IX: Julian Ursyn Niemcewicz, Powrót posła, wydany przez Józefa Wójcika, Lwów 1892 (102 strony, 1000 egzemplarzy).

Zdaniem TNSW wydawnictwo to, mimo że było bardzo „pożyteczne nie doczekało się zasłużonego poparcia"42. Rada Szkolna Krajowa planowała wydawać w nim dzieła przeznaczone do „prywatnej obowiązkowej lektury polskiej, jako uzupełnienie nauki ojczystej literatury, ale zamiaru tego nie wykonała"43. TNSW chcąc zapewnić sobie podstawy finansowe do kontynuacji wydawania dzieł, zwróciło się do Rady Szkolnej Krajowej z prośbą o „aprobatę i polecenie”44, co też Rada uczyniła. W kolejnych latach ukazały się następne tomiki ${ }^{45}$.

Tomik X: Jan Chryzostom Pasek, Pamiętniki, dla młodzieży skrócił i objaśnił Romuald Bobin, Lwów 1894, wydanie II (265 strony, 1000 egzemplarzy).

Tomik XI: Reinholda Heidensteina Pamiętniki o wojnie moskiewskiej, tłumaczył J. Czubek, Lwów 1894 (312 strony, 1000 egzemplarzy) ${ }^{46}$.

TNSW, chcąc nadal prowadzić działalność wydawniczą, zwróciło się po pomoc do Sejmu Krajowego. Jednak starania te okazały się bezskutecznie, publikacje mogły się ukazywać, tylko powoli. Jako kolejne tomiki wydano:

Tomik XII: Wybór nowel i opowiadań najznakomitszych współczesnych pisarzy polskich, zebrał Henryk Kopia, Lwów 1895.

Tomik XIII: Karol Szajnocha, Krzysztof Opaliński, wydał Franciszek Próchnicki, Lwów 1895.

Tomik XIV: Seweryn Goszczyński, Król zamczyska. Sobótka, wydał M. Mazanowski, Lwów 1896.

Tomik XV: William Szekspir, Koryolan, w tłumaczeniu Józefa Paszkowskiego, wyd. Franciszek Próchnicki, Lwów 1896.

Tomik XVI: Adam Mickiewicz, Złote myśli, zebrane przez Józefa Nogaja, Lwów 1896.

Był to ostatni tomik, ponieważ na kolejne lata, do 1901 r. zawieszono edycję tej serii. Na brak wydawnictwa zwrócono uwagę w trakcie Zjazdu TNSW w 1901 r. Wybrano wówczas specjalną komisję, która miała zająć się kontynuowaniem edycji dzieł, jednak pod zmienionym tytułem: „Biblioteka Towarzystwa Nauczycieli Szkół Wyższych". Podjęto wówczas również decyzję, że wydawane będą nie tylko nowe dzieła, a także przedruki utworów literatury narodowej wraz z objaśnieniami oraz przedmową wydawców. Aby uniknąć konkurencji, zawarto umowę z wydawcą „Arcydzieł Literatury” F. Western. W 1900 r. ukazał się Wybór

\footnotetext{
42 Tamże.

43 Tamże.

44 Tamże.

45 Tamże.

46 Tamże, s. 71.
} 
pism Mieczysława Romanowskiego, wydany przez Tadeusza Piniego, t. I-II oraz Skarbczyk poezyi polskiej, t. I-II w opracowaniu Artura Passendorfera.

Poza „Biblioteką dla Młodzieży” wydano jeszcze dwie powiastki Mieczysława Jamrógiewicza - Maciej Brzoza i Wujaszek fizyk, ok. 1906 r. ${ }^{47}$

Na bazie „Biblioteki dla Młodzieży” powstało nowe wydawnictwo: „Nauka i Sztuka"48. Plan zamierzeń wydawniczych przedstawił Tadeusz Pini w trakcie posiedzenia Wydziału TNSW dnia 11 listopada 1905 r. Jego propozycje uzyskały aprobatę.

W serii „Nauka i Sztuka” miały ukazywać się monografie popularnonaukowe z różnych dziedzin nauki, przede wszystkim z historii politycznej, historii sztu$\mathrm{ki}$, historii literatury oraz z nauk przyrodniczych. Szczególny nacisk położono na przybliżanie polskiej kultury, cywilizacji europejskiej, zwracając uwagę na postaci najwybitniejsze, epokowe. Wydział powierzył obowiązki redakcyjne Tadeuszowi Piniemu. W oddzielnym regulaminie ujął prawa i obowiązki redaktora. W ramach serii „Nauka i Sztuka” ukazały się:

- Tomik I: Ludwik Kubala, Stanisław Orzechowski, z 46 ilustracjami, Lwów 1906.

- Tomik II: Edward Porębowicz, Dante, z 73 ilustracjami, Lwów 1906.

- Tomik III: Aleksander Brückner, Dzieje języka polskiego, ze 121 ilustracjami, Lwów 1906.

- Tomik IV: Antoni Sygietyński, Maksymilian Gierymski, z 92 ilustracjami, Lwów 1906. 1907.

- Tomik V: Walery Łoziński, Ziemia i jej budowa, z 91 ilustracjami, Lwów

- Tomik VI: Antoni Potocki, Portret i krajobraz angielski, z 84 ilustracjami, Lwów 1907.

- Tomik VII: Aleksander Poliński, Dzieje muzyki polskiej, ze 147 ilustracjami, Lwów 1907.

- Tomik VIII: Władysław Kozicki, Michał Anioł, z 89 ilustracjami, Lwów 1907.

- Tomik IX: Stanisław Witkiewicz, Matejko, z 275 ilustracjami, Lwów 1907.

TNSW zamierzało również wydawać inne dzieła w językach obcych. Już w 1890 r. Wydział Towarzystwa planował przystąpić do wydawania „Biblioteki Dzieł Literatury Niemieckiej”. Miała ona pomóc młodzieży w nauce tego języka. Jednak propozycji tej nie udało się zrealizować ${ }^{49}$. $Z$ takim samym projektem wystąpił kilka lat później Jut Ippoldt. Według jego zamierzeń „Biblioteka” miała ukazywać się z objaśnieniami, przygotowanymi do potrzeb młodzieży pt. „Schulausgaben klassischer Werke"50. Ukazały się m.in. Tomik I: Franz Grillparzer, Die Ahnfrau, bearbeitet von Prof. J. Ippoldt, Lwów 1904; Tomik II: Johann Wolfgang Goethe, Egmont, bearbeitet von Prof. A. Marcinkowski, Lwów 1906; Tomik III: Gotthold

\footnotetext{
47 Tamże.

48 Tamże, s. 72.

49 Tamże.

50 Tamże, s. 73.
} 
Ephraim Lessing, Minna von Barnhelm, bearb. von Prof. St. Gayczak, Lwów 1907. Własnym nakładem TNSW wydało następujące publikacje: Antoni Karbowiak, Listy w sprawie wystawy rzeczy szkolnych polskich, Lwów 1894 oraz Józef Czernecki, Brzeżany, pamiątki i wspomnienia, Lwów $1905^{51}$.

Z inicjatywą wydawniczą wystąpiło również krakowskie koło TNSW ${ }^{52}$ pod koniec 1887 r., proponując następujące tomiki „Biblioteki Pedagogicznej”. Tomik I: Franciszek Bieliński, Sposób edukacyi w XV. listach opisany, które do Komisyi Edukacyi Narodowej od bezimiennego autora były przesyłane. R.P. 1775, wydał Stanisław Siedlecki, Kraków 1888; Tomik II: Ks. Grzegorza Piramowicza: Mowy, miane $w$ Towarzystwie do ksiąg elementarnych $w$ latach 1776-1788, wydane $w$ r. 1889 przez dra Wł. Wisłockiego.

Organem prasowym TNSW było pismo „Muzeum”, ukazujące się od 1885 do 1939 roku, które można było porównać z podobnymi, ukazującymi się „najlepszemi pismami tego rodzaju, wydawanemi w Europie i Ameryce, [...] wydane już dwadzieścia i siedem tomów są niewyczerpaną kopalnią wiedzy pedagogicznej w odniesieniu do szkół wyższych i cennem pomnożeniem niebogatej u nas literatury pedagogicznej" 53 . Odnotowywano w nim wszystkie wydarzenia z działalności TNSW, odnoszące się zarówno do statutowej działalności TNSW, do spraw dydaktycznych, wiadomości o bieżących wydarzeniach, referaty, sprawozdania z poszczególnych etapów działalności, opisywano fakty z codziennej działalności kół w poszczególnych miastach.

Działalność wydawnicza podjęta przez TNSW przyczyniała się do upowszechnienia edukacji, ułatwiała dostęp do stosunkowo dużej liczby publikacji potrzebnych nauczycielom oraz uczniom.

51 Tamże.

52 B. Łuczyńska, Koło krakowskie TNSW na tle prac Towarzystwa Nauczycieli Szkół średnich i wyższych 1884-1939, Kraków 1991, passim.

53 „Muzeum” 1909. Dodatek 1. A. Karbowiak, Towarzystwo Nauczycieli Szkół Wyższych..., s. 73. 